\title{
Qualitative Research Interviewing: Typology of Graduate Students' Interview Questions
}

Constantino T. Ballena

College of Liberal Arts and Communication-Graduate Studies

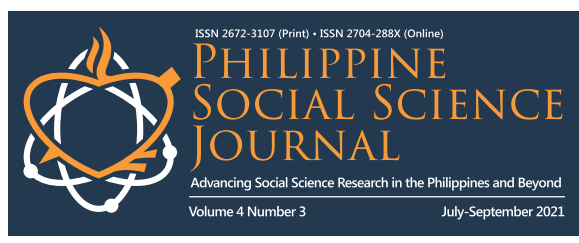

De La Salle University-Dasmariñas, City of Dasmariñas, Philippines

\section{Article history:}

Submitted: 17 June 2021

Revised: 15 October 2021

Accepted: 25 October 2021

\section{Keywords:}

Corpus linguistics

Graduate students

Interview questions

Qualitative research interview

Typology of questions

DLSU-Dasmariñas

ABSTRACT. This paper is a corpus linguistics research that examined the typology of questions asked by graduate students who did papers that solely followed qualitative research interviewing as their data collection technique. Corpus linguistics is a methodological approach employed to analyze patterns of language use in naturally occurring texts. The paper investigated the breadth and structure of the interview questions and the unproductive questions found in the corpus. The corpus consisted of 7,516 interview questions examined following the structure-breadth-function typology of questions as a framework. The corpus was analyzed by identifying the patterns of the interview questions for these to be properly typologized. Results revealed that Wh- questions (5,365 of the 7,516 questions or $71.381 \%$ ) were the most frequently asked interview questions, followed by the yes-no questions (1,455 or 19.359\%). Tell-Explain-Describe or TED questions ( 6 or $0.106 \%$ ) had the least frequency of occurrence. Additionally, closed-ended questions (3,977 or $52.914 \%$ ) were more prevalent than open-ended questions (3,539 or $47.086 \%)$. While a total of 802 prefaced questions were identified with so-prefaced questions as the most pervasive (446 or $56.611 \%)$. Finally, the study results showed that leading and multiple questions constituted the unproductive interview questions, the latter being the most preponderant with 700 or $55.556 \%$ of the 1,260 unproductive questions. The subcategorizations yes-no and wh-leading questions; and multiple yes-no, multiple yes-no-wh-, and multiple wh- (serial and single) questions are nowhere to be found in the available literature on interview questions, thus adding to the value of the present study. The quality of qualitative research interviewing is facilitated by the typology of questions interviewers asked based on the structure and breadth of the questions. Generally, the whopen-ended type is the more appropriate one in qualitative research interviewing.

\subsection{Introduction}

Interviews are the most common data collection technique (Merriam \& Tisdell, 2015; Jamshed, 2014; Qu \& Dumay, 2011; Ballena \& Liwag, 2019). Kvale and Brinkmann (2009) contended that "an interview is literally an interview, an exchange of views between two persons" (p. 2), the interviewer and the interviewee. Interviewing begins to unfold as the interviewer "asks questions of the interviewee in order to gather subjective information about a particular topic or experience" (DeJonckheere \& Vaughn, 2019, p. 2). Generally, an interview comes in any of the three forms, viz., structured, unstructured, and semi-structured-the latter is probably the most common in qualitative research (Ravitch \& Carl, 2019; Brinkmann, 2015). Interviews may come in various modalities such as individual (one-on-one) or group, face-to-face or technologymediated or online, and synchronous, near synchronous or asynchronous (Sweet, 2002; Meho, 2006; Nehls et al., 2015; Bailey \& Bailey, 2017; Denzin \& Lincoln, 2015; Ravitch \& Carl, 2019; Merriam \& Tisdell, 2015; Brinkmannet al., 2018).

A plethora of literature has been done on interviewing for the past three decades. Interview literature have focused on types of interview (Goldman \& McDonald, 1987; Minichiello et al., 2008; Morgan, 1996; Wengraf, 2001); principles and practice of interview (Arksey \& Knight, 1999; Denzin \& Lincoln, 2000; Gubrium \& Holstein, 2001; Roulston, 2010; Hannabuss, 1996; Holstein \& Gubrium, 1995; Kvale, 1996); interviewing techniques and skills (Douglas, 1985; Doyle, 2004; Kvale, 2013; Kvale \& Brinkmann, 2009; Rubin \& Rubin, 2011; McNair et al., 2008; DeJonckheere \& Vaughn, 2019); challenges in doing interview (Roulston, 2011; Adams, 2010; Brayda \& Boyce, 2014); technologymediated interview (Burnard,1994; Howard et al.,1988; Musselwhite et al., 2007; Sweet, 2002; TrierBieniek, 2012); qualitative research interview (Mero-Jaffe, 2011; Tanggaard, 2008; Brayda \& Boyce,

This article published by Philippine Social Science Journal (PSSJ) is licensed under a Creative Commons AttributionNoncommercial 4.0 International (CC BY-NC 4.0). You are free to share (copy and redistribute the material in any medium or format) and adapt (remix, transform, and build upon the material). Under the following terms, you must give appropriate credit, provide a link to the license, and indicate if changes were made. You may do so in any reasonable manner, but not in any way that suggests the licensor endorses you or your use. You may not use the material for commercial purposes. 
2014; Jamshed, 2014; Frances et al., 2009; Qu \& Dumay, 2011; Roulston, 2011); employment interview (Janz, 1982; Day \& Carroll, 2003; Campion et al., 1997; Levashina et al., 2014); and police, investigative, and courtroom interviews (Aidridge \& Cameron,1999; Cederborg et al., 2000; Daviesl et al., 2000; Fisher et al., 1987; Gibbons, 2008; Griffiths \& Milne, 2006; Holt \& Johnson, 2010; Johnson, 2002; Korkman et al., 2006; Lamb, 1996; Loftus, 1982; Myklebust \& Bjørklund, 2006). Police, investigative and courtroom interviews are the most widely studied of the foregoing.

Questions are pivotal in interviews. Quirk et al. (1985) presented a comprehensive theoretic discussion of the nature of questions, also known as interrogative sentences in grammar. "Questions primarily have the illocutionary force of inquiries" (p. 806). The three major classifications of questions based on the expected response in light of Grice's cooperative principle are (1) YES-NO questions, "[t]hose that expect affirmation or negation"; (2) WH- questions, "[t]hose that typically expect a reply from an open range of replies," and are also called informational questions; and (3) ALTERNATIVE questions, "[t]hose that expect as the reply one of two or more options presented in the questions" (p. 806). They considered tag questions and declarative questions further types of yes-no questions. The third major type of question may come in either of its two forms: (1) alternative yes-no question and (2) alternative wh-questions.

Interview questions are essentially reflective of the classifications of questions discussed in the foregoing. Studies had been carried out on employment interview questions which specifically focused on structured interview question types (Conway \& Peneno, 1999), situational and behavior description interview questions (Culbertson et al., 2017; Huffcutt et al., 2001), and asking the right questions (Hartwell et al., 2019). In addition, questions on police, investigative, and courtroom interviews have been extensively studied (Loftus, 1982; Aidridge \& Cameron, 1999; Cederborg et al., 2000; Daviesl et al., 2000; Johnson, 2002; Hartwell et al., 2019; Korkman et al., 2006; Lamb, 1996; Myklebust\& Bjørklund, 2006; Oxburgh et al., 2010; Gibbons, 2008; Cossins, 2009; Carruso \& Cross, 2012; Westcott \& Page, 2002; Zajac et al., 2012; Villanueva \& Rañosa-Madrunio, 2016). Mahmood (2014), on the other hand, examined from the vantage point of pragmatics the yes-no questions asked in press conferences arguing that "verification question" is the most appropriate term for yesno questions. Of the several studies on qualitative interview questions, only Qu and Dumay (2011) and Brayda and Boyce (2014) accentuated the types of questions in a qualitative interview. The same studies underscored the typology of Kvale (1996) and Patton (2002, 2014), respectively (cf. Table 1).

Given the centrality of questions, Merriam and Tisdell (2015) contended that multiple, leading, and yes-no questions should be avoided. Multiple questions present several points; for instance, What can you say about public speaking and the use of visual aids and nonverbal cues? Since the question underscores three points, the interviewee may not give a substantive answer to each point; thus, the inappropriateness of multiple questions (Griffiths \& Milne, 2006; Shepherd, 2007; 2013). A series of questions asked at one time is also a form of multiple questions which interviewers have to avoid. Lichtman (2006) suggested that the interviewer asks one question at a time. On the other hand, a leading question induces the interviewee to answer in a particular way (Daviesl et al., 2000; Aldridge \& Cameron, 1999; Griffiths \& Milne, 2006; Lamb, 1996; Shepherd, 2007; 2013). Avoiding leading questions is necessary for that they "reveal a bias or assumption that the [interviewer] is making." They set the interviewees up to accept the [interviewer's] point of view (Merriam \& Tisdell, 2015, pp. 121-122). The question, Does your student have some psychological problem? is a leading question. Since the yes-no question requires just a single word answer, it is considered an unproductive interview question in qualitative research. 
Table 1

Typology of Interview Questions

Quirk, et al. (1985)
1. Yes-no questions
a. Tag
b. Declarative
2. Wh-questions
3. Alternative
a. Alternative yes-no
b. Alternative Wh-

Richardson, et. al. (1974)

1. Open

2. Closed
a. Identification
b. Selection
c. Yes-no

Loftus (1982)

Closed-specific: $5 \mathrm{Wh}$

Fisher, et al. (1987)

1. Open

2. Closed

Milne and Bull (1999)

1. Open: Tell and Describe

2. Closed Specific: Wh

Daviesl, et al. (2000)
1. Open
2. Closed
3. Specific. yet not leading
4. Leading
Bailey (2018)
1. Open-ended
2. Close-ended
3. Probe
4. Follow-up
Aidridge and Cameron (1999)
1. Free reports
2. Open
3. Specific
4. Leading
5. Non-leading

Cederborg, et al. (2000)
1. Invitation
2. Directive
3. Option-posing
4. Suggestive

Griffiths and Milne (2006)

1. Productive

a. Open: Tell and Describe

b. Probing: Wh

c. Appropriate Closed: Yesno

2. Unproductive
a. Inappropriate
b. Leading
c. Forced-Choice
d. Multiple
e. Opinion or Statement

1. Open: Wh

2. closed
a. Yes-no
b. Alternative
c. Declarative
d. Tags

Johnson (2002)

1. and-prefaced

2. so-prefaced

\author{
1. Experiential and Behavioral \\ 2. Opinion and Value \\ 3. Feeling \\ 4. Knowledge \\ 5. Sensory \\ 6. Demorgraphic
}

Patton (2002 \& 2015)

Korkman, et al. (2006)

1. Facilitators

2. Clarifications

3. Invitation

4. Directive Utterances

5. Option-Posing

6. Suggestive

Shepherd $(2007,2013)$

1. Productive

a. TED: Tell, Explain, Describe

b. Probing, narrative

lexplanation seeking

c. Parameter

d. Closed Identificatory: $5 \mathrm{Wh}+$ Whose

2. Risky

a. Closed Yes-no

b. Open cofirmatory

3. Counterproductive

a.Leading

b. Option

c. Filling the pause

d. Marathon

e. Hypothetical

f. Parroting

\section{Kvale (1996)}

1. Introducing

2. Follow-up

3. Probing

4. Specifying

5. Direct

6. Indirect

7. Structuring

8. Silence

9. Interpreting

Additionally, Merriam and Tisdell (2015) argued that yes-no interview questions elicit very minimal information from the interviewees; thus, interviewers must avoid asking yes-no questions. However, both leading and yes-no questions are deemed good when used in cross-examination (Tkačukova, 2010).

Most of the foregoing literature on interviews and the typology of interview questions were on police, investigative, and courtroom interviews, which are basically in pathological and legalistic contexts. There is a dearth of literature on qualitative research interview questions (Qu \& Dumay, 2011; Brayda \& Boyce, 2014; Merriam \& Tisdell, 2015). Hence, the thrust of the present paper is to investigate qualitative research interview questions, particularly those questions asked by graduate students when they conducted their series of interviews as a requirement for their course in Qualitative Research. Specifically, the paper examined the breadth and structure (cf. Table 2) of the interview questions and the unproductive questions found in the corpus. Results of the present study could add to the existing literature on qualitative research interviews. 


\subsection{Framework of the Study}

Closer scrutiny of the various literature that particularly paid attention to interview questions could reveal further typologization based on their structure, breadth, and function (cf. Table 2); thus, the Structure-Breadth-Function Typology of Questions as the framework of the present study. Based on their structure, interview questions that had been underlined in various studies may be classified as (1) wh-questions, (2) yes-no questions, (3) alternative (4) declarative, and (5) TED (Tell-ExplainDescribe) (Loftus, 1982; Cederborg et al.,2000; Myklebust \& Bjørklund, 2006; Oxburgh et al., 2010; Shepherd, 2007; 2013; Griffiths \& Milne, 2006; Tkačukova, 2010).

In terms of breadth, questions may be classified as open-ended or closed-ended. Open-ended interview questions ask the interviewees to share their thoughts, feelings, and experiences; hence, these require more detailed responses from the interviewees. Whereas the close-ended ones ask the interviewees to give short answers likes single word or phrase responses (Richardson et al., 1974; Loftus, 1982; Fisher et al., 1987; Aldridge \& Cameron, 1999; Milne \& Bull, 1999; Daviesl et al., 2000; Griffiths \& Milne, 2006; Myklebust \& Bjørklund, 2006; Shepherd 2007, 2013; Tkačukova, 2010). Table 2 also shows 14 functions culled from existing literature that interview questions serve.

Table 2. Structure-Breadth-Function Typology Questions

\begin{tabular}{lllll}
\hline $\begin{array}{l}\text { Breadth of Prospective } \\
\text { Response }\end{array}$ & \multicolumn{3}{c}{ Structure } \\
\hline 1. Open & 1. & Wh- & 1. Facilitative & 8. Suggestive \\
2. Closed & 2. Yes-no & 2. Clarificatory & 9. Leading \\
& 3. Alternative & 3. Confirmatory & 10. Probing \\
& 4. Declarative & 4. Identificatory & 11. Interpretive \\
& 5. Tags & 5. Invitational & 12. Introducing \\
& 6. TED & 6. Directive & 13. Specifying \\
& 7. & 7. Option-posing & 14. Comparing \\
\hline
\end{tabular}

\subsection{Methods}

The Corpus.This paper employed corpus linguistics research in examining the typology of questions asked by graduate students who did papers that solely followed qualitative research interviews. Corpus linguistics is a methodological approach employed to analyze patterns of language use in naturally occurring texts. The corpus consisted of 920 pages of interview transcripts (in word file with a size of an eight-and-a-half inch by 11-and-a-half inch) with a total of 316,085 words. These interview transcripts were prepared by $29 \mathrm{ESL}$ graduate students, who conducted interviews; they were bonafide students of the College of Liberal Arts and Communication-Graduate Studies, De La Salle University-Dasmariñas, City of Dasmariñas. Conducting interviews was part of their requirements for the course Qualitative Research in English as a Second Language they were enrolled in. On average, each graduate student interviewed seven interviewees from October 2018 until January 2019 and from November 2020 until May 2021. They were asked to audio-record their interview sessions and to prepare validated transcripts of the interviews. Content-wise, the questions they asked when they held their series of interview sessions with their respective participants were based on the specific research questions of their respective studies. A total of 7,516 qualitative research interview questions were obtained from the entire corpus of the study.

Framework of Analysis. The qualitative research interview questions were analyzed in light of the breadth-structure typology of questions (Quirk et al., 1985). The breadth of interview questions is two-fold, i.e., open and closed questions. A question is deemed open-ended by its very nature when the interviewee is expected to give a detailed answer to the question. In contrast, it is closedended when the interviewee is expected to give a single-word or phrase answer. Based on the structure or the phraseology of questions, the basic typology includes yes-no questions (tag and declarative questions as further types), wh-questions, and alternative-alternative yes-no and alternative wh-question as sub-types (cf. Table 3 for illustration).

Open-ended questions are the wh-questions and TED (Milne \& Bull, 1999; Griffiths \& Milne, 2006; Shepherd, 2007; 2013); while the closed-ended ones may be wh-questions, yes-no 
questions (tag and declarative questions as further types), wh-questions, and alternative-alternative yes-no and alternative wh-question as sub-types.

The foregoing typology of questions was used to analyze the qualitative research interview questions found in the corpus. Additionally, questions (multiple and leading) to be avoided when conducting interviews were also examined (Merriam \& Tisdell, 2015; Lichtman, 2006; Lamb, 1996; Aldridge \& Cameron, 1999; Daviesl et al., 2000; Griffiths \& Milne, 2006; Shepherd 2007; 2013).

Finally, prefaced questions (Johnson, 2002) were identified. Some words like "so prefix a

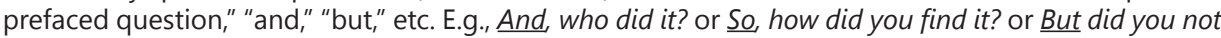
consider the audience before writing your speech?

Table 3. Samples of Questions Based on Their Structure and Breadth

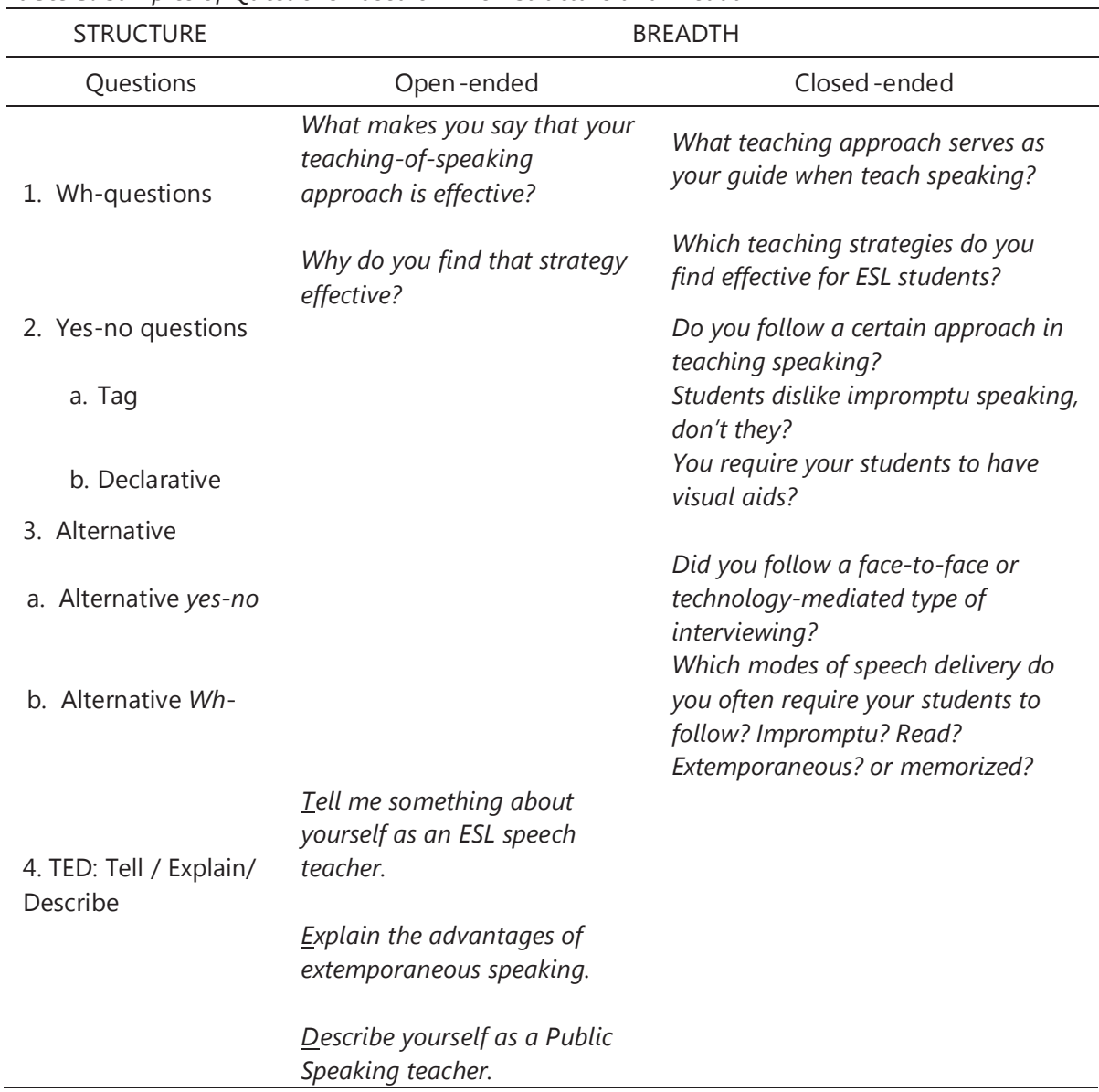

Data Analysis. The foregoing framework was used in examining the 7,516 qualitative research interview questions. No qualitative data analysis software was utilized. All the interview questions were identified and counted using Microsoft Excel and Microsoft Word. The structural typology of the questions was identified and labeled by writing codes on the margin beside each question. The codes used were wh-open; wh-closed, $\mathrm{Y} / \mathrm{N}$ for yes-no), tag, decla for declarative, alter $\mathrm{Y} / \mathrm{N}$ for alternative yes-no, alter wh- for alternative wh-, and TED for questions that started with Tell or Explain or Describe; tabulation using the Microsoft Excel followed. Microsoft Excel 2016 was used in computing the frequency and percentage of all the typologized questions. 


\subsection{Results}

\section{The structure of graduate students' interview questions}

The analysis showed that $w h$-questions topped the list of interview questions asked by graduate students, with a total of 5,365 or $71.361 \%$ of the 7,516 questions. TED questions were the least among the interview questions with only eight instances (cf. Table 4). Yes-no questions were found to be a far second.

Table 4. Typology of Questions Based on Their Structure

\begin{tabular}{lccc}
\hline Questions & $f$ & $\%$ & Rank \\
\hline Wh- & 5,365 & 71.381 & 1.0 \\
Yes-no & 1,455 & 19.359 & 2.0 \\
Tag & 116 & 1.543 & 5.0 \\
Declarative & 437 & 5.814 & 3.0 \\
Alternative & & & \\
Alternative yes-no & 121 & 1.610 & 4.0 \\
Alternative wh- & 14 & 0.186 & 6.0 \\
TED: Tell / Explain/ Describe & 8 & 0.106 & 7.0 \\
Total & 7,516 & 100.000 & \\
\hline
\end{tabular}

Notably, the how question ranked first with a frequency of 2,920 or $38.850 \%$, followed by what questions (cf. Table 9). Extract 1 illustrates examples of wh-type of questions found in the corpus.

\section{EXTRACT 1:}

Interviewer: In case you get to continue, how will you prepare?

Participant C: I will read a lot of thesis or dissertation to prepare myself. I will use those as a basis in writing in terms of format and style. Maybe I can also get some related literature.

Interviewer: Which of [your previous subjects/courses] have you benefited the most?

Participant C: My previous subjects, most particularly the Methods of Research subject, our professors showed as samples. It made me familiar with the parts.

Interviewer: How did you choose your topic?

Participant C: My professor suggested my topic since I find this part a little difficult.

Extract 2, on the other hand, shows one of the eight instances when an interviewer asked a TED question. The TED question elicited a longer answer compared to those in the first extract.

EXTRACT 2:

Interviewer: Tell me about your experience in conducting research.

Participant 2: I do my research based on my interest. Sometimes, it is stressful because if you are required to study a subject or a topic you are not interested in, you have to exert effort and read a lot.

Moreover, Extract 3 exhibits yes-no, declarative, tag, and alternative wh- questions.

EXTRACT 3:

Interviewer: Do you follow as is? [YES-NO]

Interviewee 4: I would say not all the time.

Interviewer: Well said. So, I'm assuming that you require major writing output? [DECLARATIVE] Interviewee 4: Definitely! It's something that I honestly like doing din kasi. I ask them to write coz I enjoy reading what they're writing.

Interviewer: And you do explain it, right? [TAG]

Interviewee 4: Syempre naman! 
Interviewer: How do you give feedback on their task? Oral or written? [ALTERNATIVE WH-] Interviewee 4: I usually write my feedback. It is more convenient to do it that way, considering the number of students I have. But if time permits, I also give comments orally. Usually, for general feedback, I address it to the whole class orally.

\section{The breadth of graduate students' interview questions}

Closed-ended interview questions with a total of 3,977 or $52.914 \%$ of the 7,516 were prevalent compared to the open-ended ones, which were way below $50 \%$ of the entire interview questions (cf. Table 5). On the other hand, the open-ended questions were dominated by wh-type of questions, with TED questions being the least among all the questions when categorized based on their breadth.

Table 5. Typology of Questions Based on Their Breadth

\begin{tabular}{lccc}
\hline Questions & $\mathrm{f}$ & $\%$ & Rank \\
\hline Open-ended & $\mathbf{3 , 5 3 9}$ & $\mathbf{4 7 . 0 8 6}$ & \\
Wh- & 3,531 & 46.980 & 1.0 \\
TED & 8 & 0.106 & 2.0 \\
Close-ended & $\mathbf{3 , 9 7 7}$ & $\mathbf{5 2 . 9 1 4}$ & \\
Yes-no & 2,008 & 26.716 & 1.0 \\
Wh- & 1,834 & 24.401 & 2.0 \\
Alternative & 135 & 1.220 & 3.0 \\
Total & 7,516 & 100.000 & \\
\hline
\end{tabular}

The yes-no type of questions could be further classified as yes-no, declarative, and tag. Among closed-ended interview questions, the yes-no (2,008 or $26.716 \%)$ and what (1,834 or $24.401 \%)$ ranked first and second, respectively, while the who-type question was the least (cf. Appendix A, Table 9). Whereas, the how-type question (2,920 or $38.850 \%$ ) dominated the open-ended interview questions, followed by the what with a frequency of 482 or $6.413 \%$ (cf. Appendix A, Table 8).

One form of open-ended interview questions seen in the transcript is through what way, as shown in the excerpt, follows.

EXTRACT 4:

Interviewer: How do you know if your students learned listening skills? Through what way?

Participant D: I will know that if my students learned the listening skills if they can easily understand and comprehend what is our topic all about. If I do an assessment, they can answer it easily. I think it's the best way to know if my students learned the listening skills.

This form of expression, which appeared 15 times (cf. Table 9), was asked by only one interviewer; the 28 others did not use the same expression. The same interviewer used another expression thrice in what way, which is of identical sense as exemplified in the next extract.

EXTRACT 5:

Interviewer: Do you think teaching listening is vital for junior high school students? In what way? Participant F: Yes. Listening is a very important macro skill that we use every day. Through listening task, we encourage students to critically think when listening to a simple conversation or discourse.

Although both forms serve as a follow-up question to the immediately preceding question, the through what way expression is rather unusual in the ESL context. This could be the reason why no other interviewers used the same expression. Table 9 shows how the form was used 37 times, and the corpus reveals that the same expression was used by four of the 29 interviewers.

\section{Prefaced interview questions}

Prefaced questions with a total of 802 were among the types of questions that could be gleaned from the corpus. Table 6 presents six sub-types of prefaced questions. The so-prefaced (446 or $56.611 \%)$ and well-prefaced and anyway-prefaced (1 or $0.125 \%$ ) are the most and least dominant, 
respectively. The former has the following forms: (1) so-wh-, (2) so-declarative, (3) so-yes-no), (4) so-alternative yes-no, and (5) so-tag.

Table 6. Typology of Prefaced Questions

\begin{tabular}{lccc}
\hline Questions & $\mathrm{f}$ & $\%$ & Rank \\
\hline so-prefaced & 446 & 56.611 & 1.0 \\
but-prefaced & 33 & 4.115 & 3.0 \\
and-prefaced & 307 & 38.279 & 2.0 \\
now-prefaced & 14 & 1.746 & 4.0 \\
well-prefaced & 1 & 0.125 & 5.0 \\
anyway-prefaced & 1 & 0.125 & 6.0 \\
Total & 802 & 100.00 & \\
\hline
\end{tabular}

The and-wh form had the highest frequency of occurrence (293 or $36.534 \%$ ), as shown in Appendix C (Table 10). The prefaced interview questions could be illustrated in the excerpts that follow. EXTRACT 6:

Interviewer: Ah okay. So, do you follow the stages of writing? [SO-YES-NO]

Participant B: Yes.

Interviewer: So, what are the foci of the writing activity that you give to your students? [SO-WH-]

Participant B: Most of the time, I always focus on the content and how it is presented, the teaching styles of the student.

Interviewer: Now, how is it taught? [NOW-WH-]

Participant B: For example, I ask them to a book review. So first, I am teaching them how to do a book review, and then I allow them to look for examples, and that's it.

Interviewer: But, how do you motivate them to write? [BUT-WH-]

Participant B: I motivate them to write because I always tell them that once they reach College, they will still do the writing.

Interviewer: And, what do you observe in your students or to your students when you give them writing task? [AND-WH-]

Participant B: I usually observe that some of them are really good in writing.

Interviewer: So, you have a rubric. Are the rubrics explained? [SO-DECLARATIVE]

Participant B: Yes.

\section{EXTRACT 7:}

Interviewer: So, is it written or oral? [SO-ALTERNATIVE YES-NO]

Participant 6: Oral, sometimes if I'll be able to give cause I have mentioned I'm writing very fast so that I'll be able to remember what I have focus on usually verbal.

The prefaced interview questions were prefixed by single words such as and, but, so, now, well, and anyway.

\section{Unproductive interview questions}

A careful analysis of the corpus revealed three types of interview questions that are deemed unproductive in the conduct of qualitative research-yes-no, leading, and multiple questions, as shown in Table 7. Multiple interview questions were the topmost type garnering a total of 700 or $55.556 \%$ of the 1,260 unproductive questions found in the corpus. The structural aspect of the questions revealed three types of multiple interview questions, namely: (1) multiple yes-no, (2) multiple yes-no-wh-, and (3) multiple wh-. The latter had two subtypes based on the number of questions asked: serial multiple question $w h$ - and single multiple $w h-$. 
Table 7. Typology of Unprotected Questions

\begin{tabular}{|c|c|c|c|}
\hline Questions & $f$ & $\%$ & Rank \\
\hline Yes-no & 92 & 7.302 & 3.0 \\
\hline \multicolumn{4}{|l|}{ Leading } \\
\hline Yes-no & 412 & & \\
\hline Wh- & 56 & & \\
\hline Subtotal & 468 & 37.143 & 2.0 \\
\hline \multicolumn{4}{|l|}{ Multiple } \\
\hline Multiple yes-no & 66 & & \\
\hline Multiple yes-no-wh- & 182 & & \\
\hline \multicolumn{4}{|l|}{ Multiple wh- } \\
\hline Serial & 292 & & \\
\hline Single & 69 & & \\
\hline Subtotal & 700 & 55.556 & 1.0 \\
\hline Total & 1,260 & & \\
\hline
\end{tabular}

Serial and single multiple questions are illustrated in EXTRACTS 8 and 9, respectively.

EXTRACT 8:

Interviewer: How did you begin with your introduction? What preparations have you done?

Participant 6: Research, I did a lot of research talaga tapos nagbasa ng mga related literature.

\section{EXTRACT 9:}

Interviewer: How did your academic writing, qualitative research, quantitative research, and other courses help you?

Interviewee: My previous subjects, I think it helped me to acquire the necessary skills. For example, my quali and quanti allowed me to understand what research writing is.

A serial type of multiple wh-interview questions contains two or more wh-questions that are asked all at once. EXTRACT 8 exemplifies it in that the interviewer asked two wh-questions (how and what) at a time. Said questions required a detailed response from participant 6 . However, the manner these questions had been asked (both questions asked at a time) resulted in the clipped answer. That is, minimal information was elicited. The response was a cursory answer to the second wh- question. EXTRACT 9, on the other hand, shows an instance of a single type of multiple whquestion. The singularity of the question is structural, that is, it is just one interrogative question notwithstanding its multiple foci: academic writing, qualitative research, quantitative research, and other courses. Similarly, the response was very cursory.

The second and third types of multiple questions are multiple-yes-no-wh and multiple yes-no, as can be demonstrated in EXTRACTS 10 and 11, respectively.

EXTRACT 10: multiple yes-no-wh interview question

Interviewer: Does viewing activity engages [sic] the students more on the lesson? How do you ensure students' engagement in the viewing activity? What are your means of getting feedback from them?

Interviewee: yes. It makes them alive inside the classroom. Asking questions about videos helps me know if the students understand the lesson well.

EXTRACT 11: multiple yes-no interview question Interviewer: Alright. Thank you po. Do you teach listening as part of writing? Viewing? Speaking? Reading? Participant 1: Of course, it is already a part of viewing and ... and reading. I normally presented video that will make them listen to, or I, I used to read a particular piece which they need to listen, that's, that's I always do.

A multiple yes-no-wh type interview question consists of at least one yes-no combined with one 
wh- question asked at a time. EXTRACT10 exhibits an example of this type in that the interviewer asked one yes-no (the first question) and three wh- (the three subsequent questions). Such manner of asking questions gave rise to a very brief answer, which was cursorily responsive to the first and last of the four questions asked by the interviewer. A multiple yes-no interview question, on the other hand, constitutes at least two yes-no questions that are asked all at once. In EXTRACT 11, the interviewer asked a yes-no type, which may be considered based on its constituent elements as four separate sentences, albeit the next three underwent transformation deletion. Close scrutiny of the answer of Participant 1 revealed that it was responsive only to the second (on viewing) and third (on reading) question, leaving the first (on writing) and the third (on speaking) unanswered altogether.

Leading questions ranked second in the list of unproductive interview questions with a frequency of 468 or $37.143 \%$ of the entire 1,260 unproductive questions (Table 7). Leading questions had two forms, namely, yes-no and wh- as illustrated in EXTRACTS 12 and 13. The yes-no type of leading question had been more pervasive than the wh-question as demonstrated in their respective frequency of occurrences in the corpus-206 and 28.

EXTRACT 12: yes-no leading question

Interviewer: Do you immediately provide corrective feedback?

Participant: Yes, but in a nice way.

Interviewer: In front of the class?

Participant: Yes.

Interviewer: So you immediately give, ma'am?

Participant: Yes.

EXTRACT 13: wh-leading question

Interviewer: What is the common problem you encounter when teaching writing?

Interviewee 3: Mostly, the greatest problem when it comes to teaching writing is the students who don't see anything good in writing. Yung mga students who are having a hard time to express themselves into words.

The words "immmediately" and "In front of the class" in EXTRACT 12 made the yes-no question leading. They induced the interviewee to answer the question following the bias of the interviewerthe immediacy of giving corrective feedback and where such is given (in front of the class). By asking Do you immediately provide corrective feedback? and In front of the class?, the interviewer prompted the interviewee to answer in a particular way. The answers to the two questions were suggested in the questions themselves, hence leading. EXTRACT 13 also demonstrates how the leading question is committed in the form of wh-. The words "the common" made the wh- question leading because the bias of the interviewer was on the problem that is commonly encountered by the interviewee when teaching writing - the article suggests definitiveness of the interviewee's answer; the problem to be identified should be common. Looking at the response, the interviewee identified "the greatest problem," which was students not seeing "anything good in writing." Nevertheless, the greatest problem may not necessarily be the common problem. 
Table 8. Typology of open-and-close-ended questions

\begin{tabular}{|c|c|c|c|}
\hline Questions & Frequency & $\%$ & Rank \\
\hline \multicolumn{4}{|l|}{ Ppen-ended } \\
\hline How & 2,920 & 38.850 & 1.0 \\
\hline What & 482 & 6.413 & 2.0 \\
\hline Why & 77 & 1.024 & 4.0 \\
\hline In what way & 37 & 0.492 & 3.0 \\
\hline Through what way & 15 & 0.200 & 5.0 \\
\hline TED & 8 & 0.106 & 6.0 \\
\hline Sub-total & 3,539 & 47.086 & \\
\hline \multicolumn{4}{|l|}{ Close-ended } \\
\hline Yes-no & 1,455 & 19.359 & 1.0 \\
\hline What & 1,234 & 16.418 & 2.0 \\
\hline Which & 260 & 3.459 & 3.0 \\
\hline Declarative & 437 & 5.814 & 3.0 \\
\hline What about & 219 & 2.914 & 4.0 \\
\hline Alternative yes-no & 121 & 1.610 & 5.0 \\
\hline Tag & 116 & 1.543 & 6.0 \\
\hline How long & 34 & 0.452 & 8.5 \\
\hline How about & 34 & 0.452 & 8.5 \\
\hline When & 21 & 0.279 & 10.0 \\
\hline Alternative wh- & 14 & 0.186 & 11.0 \\
\hline How many & 13 & 0.173 & 12.0 \\
\hline Where & 8 & 0.106 & 13.0 \\
\hline How often & 6 & 0.080 & 14.0 \\
\hline Who & 4 & 0.053 & 15.0 \\
\hline Sub-total & 3,977 & 52.914 & \\
\hline TOTAL & 7,516 & 100.000 & \\
\hline
\end{tabular}


Table 9. Questions based on their structure

\begin{tabular}{|lrrr|}
\hline Questions & Frequency & $\%$ & Rank \\
How & 2,920 & 38.850 & 1.0 \\
What & 1,716 & 22.831 & 2.0 \\
Yes-no & 1,455 & 19.359 & 3.0 \\
Declarative & 437 & 5.814 & 4.0 \\
Which & 260 & 3.459 & 5.0 \\
Transition & 219 & 2.914 & 6.0 \\
Questions-What & & & \\
about & 121 & 1.610 & 7.0 \\
Alternative yes-no & 116 & 1.543 & 8.0 \\
Tag & 77 & 1.024 & 9.0 \\
Why & 37 & 0.492 & 10.0 \\
In what way & 34 & 0.452 & 11.5 \\
How long & 34 & 0.452 & 11.5 \\
Transition & & & \\
Questions-How & & & \\
about & 21 & 0.279 & 13.0 \\
When & 15 & 0.200 & 14.0 \\
Through what way & 14 & 0.186 & 15.0 \\
Alternative wh- & 13 & 0.173 & 16.0 \\
How many & 8 & 0.106 & 17.5 \\
TED & 8 & 0.106 & 17.5 \\
Where & 6 & 0.080 & 19.0 \\
How often & 4 & 0.053 & 20.0 \\
Who & 1 & 0.013 & 21.0 \\
How much & & 100.000 & \\
& & & \\
\hline
\end{tabular}

Table 10. Prefaced questions

\begin{tabular}{|c|c|c|c|}
\hline Questions & Frequency & $\%$ & Rank \\
\hline and-wh & 293 & 36.534 & 1.0 \\
\hline so-wh & 173 & 21.571 & 2.0 \\
\hline so-declarative & 147 & 18.329 & 3.0 \\
\hline so-yes-no & 105 & 13.092 & 4.0 \\
\hline but-yes-no & 20 & 2.494 & 5.0 \\
\hline so-tag & 18 & 2.244 & 6.0 \\
\hline now-wh & 13 & 1.621 & 7.0 \\
\hline but-wh & 10 & 1.247 & 8.0 \\
\hline and-yes-no & 6 & 0.748 & 9.0 \\
\hline and-declarative & 5 & 0.623 & 10.0 \\
\hline so-alternative yes-no & 3 & 0.374 & 12.0 \\
\hline and-tag & 3 & 0.374 & 12.0 \\
\hline but-declarative & 3 & 0.374 & 12.0 \\
\hline now-yes-no & 1 & 0.125 & 15.0 \\
\hline well-yes-no & 1 & 0.125 & 15.0 \\
\hline anyway-yes-no & 1 & 0.125 & 15.0 \\
\hline TOTAL & 802 & 100.000 & \\
\hline
\end{tabular}




\subsection{Discussion}

The foregoing results revealed the typology of interview questions according to their structure and breadth and the typology of prefaced and unproductive questions. Interview questions were categorized as wh-, yes-no, alternative, and TED questions based on structure, and open-ended and closed-ended based on their breadth. The wh-open-ended questions came out to be the more prevalent ones compared to the other subcategories of open-ended and closed-ended questions. This particular result reflects the very nature of questions that should be asked when one conducts an interview (Myklebust \& Bjørklund, 2006; Griffiths \& Milne, 2006; Tkačukova, 2010), and more specifically in qualitative research interviewing (Merriam \&Tisdell, 2015; Bailey \& Bailey, 2017; Shepherd, 2007; 2013; Denzin \& Lincoln, 2015). The wh-open-ended questions are deemed the most appropriate. By their very nature, they require more detailed information about what is being asked. Whereas, a close-ended type, which, in the present study, was found to be more dominant when all its subcategories (yes-no, wh-, and alternative) are lumped together, is generally discouraged, especially the yes-noonesbecause these elicit very minimal to no information (Merriam \& Tisdell, 2015; Bailey \& Bailey, 2017), hence not quite productive in qualitative research interviewing. However, when the same is used in legal and judicial interview contexts, yes-no questions are deemed productive and appropriate (Daviesl et al., 2000; Griffiths \& Milne, 2006; Myklebust \& Bjorklund, 2006; Aidridge \& Cameron, 1999; Tkačukova, 2010).

Despite the very low frequency of TED questions in the present study, this open-ended type of interview question has been regarded as productive (Griffiths \& Milne, 2006; Shepherd, 2007; 2013). It encourages the interviewee to give a detailed answer to a TED question.

With regard to unproductive questions, only multiple, leading, and yes-no questions were identified in the study. These should be avoided when conducting interviews because the interviewer could not elicit substantial information (Merriam \& Tisdell, 2015). Although Griffiths and Milne (2006)and Shepherd $(2007,2013)$ agreed that leading and multiple questions are not productive, they do not concur in the unproductiveness of yes-no questions. In fact, Griffiths and Milne believed that yes-no questions are appropriate closed-ended questions, especially in police interviews. At the same time, Shepherd $(2007,2013)$ labeled these as risky closed-ended questions but not necessarily counterproductive. Yes-no questions are likewise not counterproductive and objectionable in judicial proceedings, particularly in cross-examinations, "[w]hen there is difficulty in getting intelligible answers from a witness who is ignorant, or a child of tender years, or is feeble minded, or a deaf-mute;" when directed to an unwilling or hostile witness (Section 10, Rule 132, Rules of Court, Philippine jurisdiction); and in "all stages of examination of a child if the same will further the interest of justice" (Section 20, Rule on the Examination of Child Witnesses, Philippine jurisdiction). Yes-no questions may either be productive or unproductive depending on the value of the answer sought by the interviewer.

It is worth noting that the present study has given subcategorizations of leading and multiple interview questions. The subcategorizations yes-no and $w h$ - leading questions; and multiple yes-no, multiple yes-no-wh-, and multiple wh- (serial and single) questions are nowhere to be found in the available literature on interview questions, thus adding to the value of the present study.

Finally, prefaced questions are among the typology of questions studied in legal and judicial contexts (Johnson, 2002; Villanueva \& Rañosa-Madrunio, 2016). Johnson (2002) had an in-depth study of so-prefaced questions, particularly in formal police interviews. As established by previous studies, the words "so," "and," and "but" could preface a question. In addition to these words, the present study found "now," "well," and "anyway" as words that could prefix a question; hence, the addition of now-prefaced, well-prefaced, and anyway-prefaced in the typology of prefaced interview questions. The words that serve as a preface maintain the cohesiveness of thought during the interview.

\subsection{Conclusion}

The quality of qualitative research interviewing is facilitated by the typology of questions interviewers asked based on the structure and breadth of the questions. Generally, the wh-openended type is the more appropriate one in qualitative research interviewing as these elicit much information from the interviewees. Such typology of questions was demonstrated by the graduate ESL students. Corollarily, the unproductive nature of leading and multiple questions makes it inappropriate in qualitative research interviewing. Graduate ELS students, as interviewers, are no 
exemption from falling into the trap of asking these types of unproductive questions when they employ interviewing as one of their data collection techniques.

\subsection{Limitations}

The thrust of the present study was to investigate qualitative research interview questions, particularly those which were asked by graduate students (MAESL) when they conducted their series of interviews as a requirement for their course in Qualitative Research. Specifically, the paper examined the breadth and structure of the interview questions and the unproductive questions asked by the graduate students. Notwithstanding the successful conduct of the study, it has had several limitations. A thorough analysis of the responses of the interviewees, especially the impact of the interview question typology, was not undertaken. The study did not also consider the functions of the different interview questions asked by the graduate ESL students, although a theoretic framework is provided in the introduction. Finally, the gender of the interviewers (graduate ELS students) was not considered a factor in the corpus analysis.

\subsection{Future Research}

The foregoing limitations of the present study open some suggestions for future research. First, extensive and intensive research focusing on how the typology of questions impacts the responses of the interviewees. Such a study would establish empirical support for the worth of a type of question based on the answers of the interviewees. Second, another study could be had on the functions of the different interview questions asked by interviewers. Results of such research would be of value with respect to the judiciousness of interviewers when asking questions, bearing in mind the function that corresponds to the questions in relation to the purpose of the conduct of the interview. Third, the gender of the interviewers may be a worthwhile focus of a different study. It could investigate the typology of questions asked by male and female interviewers, male and female interviewees, and/ or lesbian-gay-etc., interviewer and male interviewee or vice versa, lesbian-gay-etc. interviewer and female interviewee or vice versa, or any combination.

In addition, in-depth research on prefaced questions such as well-prefaced, now-prefaced, and anyway-prefaced questions from the vantage point of pragmatics may be undertaken. Finally, an intensive study could be carried out to examine the productiveness of yes-no interview questions as this type has been generally frowned upon by authorities in qualitative research interviewing.

\subsection{Acknowledgments}

My heartfelt gratitude to De La Salle University-Dasmariñas and the College of Liberal Arts and Communication-Graduate Studies through the University Research Office for its magnanimity in funding the entire conduct of the research.

\section{REFERENCES}

Adams, E. (2010). The joys and challenges of semi-structured interviewing. Community Practitioner: The Journal of the Community Practitioners' and Health Visitors' Association. 83. 18-21.

Aidridge, J., \& Cameron, S. (1999). Interviewing child witnesses: Questioning techniques and the role of training. Applied Developmental Science, 3(2), 136-147. https://doi.org/10.1207/s1532480xads0302_7

Arksey, H., \& Knight, P. T. (1999). Interviewing for social scientists: An introductory resource with examples. Thousand Oaks, CA: Sage.

Bailey, C. R., \& Bailey, C. A. (2017). A guide to qualitative field research. Sage Publications.

Ballena, C.T., \&Liwag, E.F. (2019). Carpe diem or carpe thesis? How graduate students deal with their thesis writing. International Journal of Research, 6, 68-76.

Brayda, W. C., \& Boyce, T. D. (2014). So you really want to interview me?: navigating "sensitive" qualitative research interviewing.International Journal of Qualitative Methods, 318334. https://doi.org/10.1177/16094069140130 0115.

Brinkmann, S. (2015). The interview. In Denzin, N. K., \& Lincoln, Y. S. (Eds.). The sage handbook of qualitative research. Los Angeles, CA: Sage Publications.

Brinkmann, S., Flick, U., \& Kvale, S. (2018). Doing interviews. Sage Publications Ltd.

Burnard, P. (1994). The telephone interview as a data collection method. Nurse Education Today, 14(1), 6772. https://doi.org/10.1016/0260-6917(94)90060-4

Campion, M. A., Palmer, D. K., \& Campion, J. E. (1997). A review of structure in the selection interview. Personnel Psychology, 50, 655-702. https://doi.org/10.1111/j.1744-6570.1997.tb01488.x. 
Carruso, D., \& Cross, T. (2012). The case in Australia for further reform to the cross-examination and court management of child witness. The International Journal of Evidence and Proof, 364-397. https://doi. org/10.1350/jep.2012.16.4.412

Cederborg, A.C., Orbach, Y., Sternberg, K. J., \& Lamb, M. E. (2000). Investigative interviews of child witnesses in Sweden. Child Abuse \& Neglect, 24(10), 1355-1361. https://doi.org/10.1016/s0145-2134(00)00183-6

Conway, J. M., \& Peneno, G. M. (1999). Comparing structured interview question types: Construct validity and applicant reactions. Journal of Business and Psychology, 13, 485506. https://doi. org/10.1023/A:1022914803347.

Cossins, A. (2009). Cross-examinations in child sexual assault trials: Evidentiary safeguard or an opportunity to confuse? Law Review, 33, 68-104.

Culbertson, S. S., Weyhrauch, W. S., \& Huffcutt, A. I. (2017). A tale of two formats: Direct comparison of matching situational and behavior description interview questions. Human Resource Management Review, 27, 167-177. https://doi.org/10.1016/j.hrmr. 2016.09.009.

Daviesl, G. M., Westcott, H. L., \& Horan, N. (2000). The impact of questioning style on the content of investigative interviews with suspected child sexual abuse victims. Psychology, Crime \& Law, 6(2), 81-97. https://doi. org/10.1080/10683160008410834

Day, A. L., \& Carroll, S. A. (2003). Situational and patterned behavior description interviews: A comparison of their validity, correlates, and perceived fairness. Human Performance, 16, 25-47. https://doi.org/10.1207/ S15327043HUP1601_2.

DeJonckheere, M.,\& Vaughn, L.M. (2019), Semistructured interviewing in primary care research: a balance of relationship and rigour. Family Medicine and Community Health, 7(2). https://doi.org/10.1136/fmch-2018000057

Denzin, N. K., \& Lincoln, Y. S. (2015). The Sage handbook of qualitative research. Los Angeles, CA: Sage Publications.

Denzin, N.K., \& Lincoln, Y.S. (2000). Introduction: The discipline and practice of qualitative research. In Denzin, N.K. \& Lincoln, Y.S. (Eds), Handbook of Qualitative Research, Sage. Thousand Oaks, CA: Sage.

Douglas, J. D. (1985). Creative interviewing. Beverly Hills: Sage Publications.

Doyle, J.K. (2004). Introduction to interviewing techniques. In Wood, D.W. (Ed.), Handbook for IQP Advisors and Students. Worcester Polytechnic Institute, Worcester, MA.

Fisher, R. P., Geiselman, R. E.,\& Raymond, D. S. (1987) Critical analysis of police interview techniques. Journal of Police Science and Administration 15(3): 177-185.

Frances, R., Coughlan, M., \& Cronin, P. (2009). Interviewing in qualitative research. International Journal of Therapy and Rehabilitation. 16. 309-314. https://doi.org/10.12968/ijtr.2009.16.6.42433.

Gibbons, J. (2008). Questioning in common law criminal courts. In J. Gibbons \& M.T. Turrel (Eds.), Dimensions of Forensic Linguistics (pp. 115-130). Amsterdam/Philadelphia: John Benjamins Publishing Company.

Goldman, A. E., \& McDonald, S. S. (1987). The group depth interview: Principles and practices. Englewood Cliffs, NJ: Prentice-Hall.

Griffiths, A., \&Milne, R. (2006). Will it all end in tiers? Police interviews with suspects in Britain. In T. A. Williamson (ed.) Investigative Interviewing: Rights, research, regulation 167-189. Devon: Willan.

Gubrium, J., \& Holstein, J. A. (2001). From the individual interview to the interview society. In Gubrium, J. F. \& Holstein, J. A. (Eds.), Handbook of interview research: Context and method (pp. 1-32). Thousand Oaks: Sage.

Hannabuss, S. (1996), "Research interviews", New Library World, Vol. 97 No. 1129, pp. 22-30.

Hartwell, C. J., Johnson, C. D., \& Posthuma, R. A. (2019). Are we asking the right questions? Predictive validity comparison of four structured interview question types. Journal of Business Research, 100, 122-129. https:// doi.org/10.1016/j.jbusres.2019.03.026

Holstein, J. A., \& Gubrium, J. F. (1995). The active interview. Thousand Oaks, CA: SAGE Publications.

Holt, E., \& Johnson, A. (2010). Socio-pragmatic aspects of legal talk: Police interviews and trial discourse. In The Routledge Handbook of Forensic Linguistics. Routledge Handbooks in Applied Linguistics. Routledge, pp. 21-36.

Howard, B. J., Meade, P. A., Booth, D., \& Whall, A. (1988). The telephone interview.Applied Nursing Research, 1(1), 45-46. https://doi.org/10.1016/s0897-1897(88)80048-x

Huffcutt, A. I., Weekley, J. A., Wiesner, W. H., DeGroot, T. G., \& Jones, C. (2001). Comparison of situational and behavior description interview questions for higher-level positions. Personnel Psychology, 54, 619-644. https://doi.org/10.1111/j.1744-6570.2001.tb00225.x.

Jamshed S. (2014). Qualitative research method-interviewing and observation. Journal of basic and clinical pharmacy, 5(4), 87-88. doi:10.4103/0976-0105.141942.

Janz, T. (1982). Initial comparisons of patterned behavior description interviews versus unstructured interviews. Journal of Applied Psychology, 67, 577-580. https://doi.org/ 10.1037/0021-9010.67.5.577.

Johnson, A. (2002). So...?: Pragmatic implications of so-prefaced questions in formal police interviews. In Cotterill, J. (Ed.) Language in the Legal Process. New York, N.Y.: Palgrave Macmillan.

Korkman, J., Santtila, P., \& Sandnabba, N. K. (2006). Dynamics of verbal interaction between interviewer and child in interviews with alleged victims of child sexual abuse. Scandinavian Journal of Psychology, 47(2), 109-119. https://doi.org/10.1111/j.1467-9450.2006.00498.x

Kvale, S. (1996). Interviews: An introduction to qualitative research interviewing. Thousand Oaks, CA: Sage. 
Kvale, S. (2013). Doing interviews. Los Angeles: Sage.

Kvale, S., \& Brinkmann, S. (2009). Interviews: Learning the craft of qualitative research interviewing (2nd ed.). Los Angeles, London, New Delhi \& Singapore: Sage.

Lamb, M. E. (1996). Effects of investigative utterance types on Israeli children's responses. International Journal of Behavioral Development, 19(3), 627-638. https://doi.org/10.1080/016502596385721

Levashina, J., Hartwell, C. J., Morgeson, F. P., \& Campion, M. A. (2014). The structured employment interview: Narrative and quantitative review of the recent literature. Personnel Psychology, 67, 241-293. https://doi. org/10.1111/peps.12052.

Lichtman, M. (2006). Qualitative research in education: A user's guide. Los Angeles: SAGE Publications.

Loftus, E. (1982). Interrogating eyewitnesses - good questions and bad. In R. Hogarth (ed.) Question framing and response consistency (51-63). San Francisco: Josey-Bass.

Mahmood, R. (2014). A Pragmatic Analysis of Yes/No Questions in English with Reference to Press Conferences. Procedia - Social and Behavioral Sciences, 136, 36-40. 10.1016/j.sbspro.2014.05.283.

McNair, R., Taft, A., \& Hegarty, K. (2008). Using reflexivity to enhance in-depth interviewing skills for the clinician researcher. BMC Medical Research Methodology, 8(1), 1-6. https://doi.org/10.1186/1471-2288-8-73.

Meho, L. I. (2006). E-mail interviewing in qualitative research: A methodological discussion. Journal of the American Society for Information Science and Technology, 57(10), 1284-1295. https://doi.org/10.1002/ asi.20416

Mero-Jaffe, I. (2011). 'Is that what I said?' Interview transcript approval by participants: An aspect of ethics in qualitative research. International Journal of Qualitative Methods, 231-247. https://doi. org/10.1177/160940691101000304

Merriam, S. B., \& Tisdell, E. J. (2015). Qualitative research: A guide to design and implementation. Vancouver, B.C.: Langara College.

Milne, R., \& Bull, R. (1999). Investigative interviewing: Psychology and practice. Chichester: Wiley.

Minichiello, V., Aroni, R., \& Hays, T. N. (2008). In-depth interviewing: Principles, techniques, analysis. Pearson Education Australia.

Morgan, D. L. (1996). Focus groups as qualitative research. Thousand Oaks, CA: Sage Publications.

Musselwhite, K., Cuff, L., Mcgregor, L., \& King, K. M. (2007). The telephone interview is an effective method of data collection in clinical nursing research: A discussion paper. International Journal of Nursing Studies, 44(6), 1064-1070. https://doi.org/10.1016/j.ijnurstu.2006.05.014

Myklebust, T., \& Bjørklund, R. A. (2006). The effect of long-term training on police officers use of open and closed questions in field investigative interviews of children (FIIC) Journal of Investigative Psychology and Offender Profiling, 3(3), 165-181. https://doi.org/10.1002/jip.52.

Nehls, K., Smith, B. D., \& Schneider, H. A. (2015). Video-conferencing interviews as a data collection method. Enhancing Qualitative and Mixed Methods Research with Technology, 140-157.

Oxburgh, G. E., Myklebust, T., \& Grant, T. (2010). The question of question types in police interviews: A review of the literature from a psychological and linguistic perspective. International Journal of Speech Language and the Law,17(1). https://doi.org/10.1558/ijsll.v17i1.45

Patton, M. Q. (2002). Qualitative research \& evaluation methods. California: Sage Publications Limited.

Patton, M. Q. (2014). Qualitative research \& evaluation methods: Integrating theory and practice. Thousand Oaks, CA: SAGE Publications, Inc.

Qu, S., \& Dumay, J. (2011). The qualitative research interview. Qualitative Research in Accounting \& Management, Vol. 8 No. 3, pp. 238-264. https://doi.org/10.1108/11766091111162070.

Quirk, R., Greenbaum, S., Leech, G., \& Svartvik, J. (1985). A comprehensive grammar of the English language. London: Longman.

Ravitch, S. M. \& Carl, M. N. (2016). Qualitative research: Bridging the conceptual, theoretical, and methodological. Sage Publications, Inc.

Richardson, S. A., Dohrenwend, B. S., \& Klein, D. (1974).Interviewing: Its forms and functions. New York: Basic Books.

Roulston, K. (2010). Reflective interviewing: A guide to theory and practice. London \& Thousand Oaks, CA: Sage.

Roulston, K. (2011). Working through challenges in doing interview research. International Journal of Qualitative Methods, 348-366. https://doi.org/10.1177/160940691101000404.

Rubin, H. J., \& Rubin, I. S. (2011). Qualitative interviewing: The art of hearing data. Los Angeles: Sage.

Shepherd, E. (2007). Investigative Interviewing: The conversation management approach. Oxford: Oxford University Press.

Shepherd, E. (2013). Investigative interviewing: The conversation management approach. Oxford University Press.

Sweet, L. (2002). Telephone interviewing: Is it compatible with interpretive phenomenological research? Contemporary Nurse, 12(1), 58-63. https://doi.org/10.5172/conu.12.1.58

Tanggaard, L. (2008). Objections in research interviewing. International Journal of Qualitative Methods, 1529. https://doi.org/10.1177/160940690800700302.

Tkačuková, T. (2010). Representing oneself. Cross-examination questioning: Lay people as crossexaminers. In M. Coulthard \& A. Johnson (Eds.), The Routledge handbook of forensic linguistics (pp. 333-346). London and New York: Routledge. 
Trier-Bieniek, A. (2012). Framing the telephone interview as a participant-centred tool for qualitative research: A methodological discussion. Qualitative Research, 12(6), 630644. https://doi.org/10.1177/1468794112439005

Villanueva, V. \& Rañosa-Madrunio, M. (2016). Examining the language in the courtroom interrogation of vulnerable and non-vulnerable witnesses. In Philippine Journal of Linguistics 47 (2016) $28-45$.

Wengraf, T. (2001). Qualitative research interviewing: Biographic narrative and semi-structured methods. London: Sage.

Westcott, H., \& Page, M. (2002). Cross-examination, sexual abuse, and child witness identity. Child Abuse Review, 11, 137-152. https://doi.org/10.1002/car.739

Zajac, R., O'Neil, S., \& Hayne, H. (2012). Disorder in the courtroom? Child witness under cross-examination. Developmental Review, 32, 181-204. https://doi.org/10.1016/j.dr.2012.06.006

\section{Correspondence:}

\section{CONSTANTINO T. BALLENA}

constantinoballena@gmail.com

ctballena@dlsud.edu.ph

https://orcid.org/0000-0002-8772-0881 